\title{
C2 domains as protein-protein interaction modules in the ciliary transition zone
}

\author{
K Remans ${ }^{*}$, M Bürger, I Vetter, A Wittinghofer \\ From Cilia 2014 - Second International Conference \\ Paris, France. 18-21 November 2014
}

RPGRIP1 (RPGR interacting protein 1) is mutated in the severe eye disease Leber's Congenital Amaurosis (LCA), while the structural homologue RPGRIP1L (RPGRIP1like) is mutated in many different ciliopathies. Both are large multi-domain proteins predicted to interact with RPGR, the Retinitis Pigmentosa G-Protein Regulator. RPGR is mutated in X-linked Retinitis Pigmentosa and located in photoreceptors and in primary cilia. We solved the crystal structure between the RPGR-interacting domain (RID) of RPGRIP1 and RPGR and demonstrate that RPGRIP1L binds to RPGR in a similar mode. RPGRIP1 binding to RPGR affects the interaction with PDEð, the cargo shuttling factor for prenylated ciliary proteins. The RPGRIP1-RID is a type II C2 domain with a canonical $ß$-sandwich structure. However, it does not bind $\mathrm{Ca}^{2+}$ and/or phospholipids and thus constitutes a new type of protein-protein interaction module. Judging from the large number of $\mathrm{C} 2$ domains present in nearly all ciliary transition zone proteins identified, the structure presented here seems to constitute a cilia-specific module present in multi-protein transition zone complexes.

Published: 13 July 2015

doi:10.1186/2046-2530-4-S1-P65

Cite this article as: Remans et al:: C2 domains as protein-protein interaction modules in the ciliary transition zone. Cilia 2015 4(Suppl 1): P65.

Max Planck Institute for Molecular Physiology, Dortmund, Germany

Submit your next manuscript to BioMed Central and take full advantage of:

- Convenient online submission

- Thorough peer review

- No space constraints or color figure charges

- Immediate publication on acceptance

- Inclusion in PubMed, CAS, Scopus and Google Scholar

- Research which is freely available for redistribution 